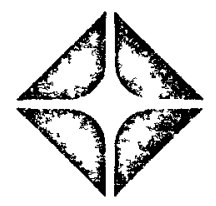

\title{
PROCESS SPECIFICATIONS AND STANDARDS \\ FOR THE 1970 THORIUM CAMPAIGN \\ IN THE PUREX PLANT
}

June 30,1970

R. E. Van der Cook and G. L. Ritter

PREPARED FOR THE U.S. ATOMIC ENERGY COMMISSION UNDER CONTRACT AT(45-1) 2130

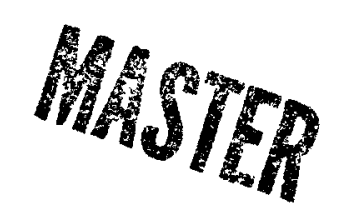

\section{PRELININARY REPORT}

THIS REPORT CONTAINS INFORMATION OF APRELIMINARY NATURE. IT IS SUBJECT TO REVISION OR CORRECTION AND THEREFORE DOES NOT REPRESENT A FINAL REPORT. IT WAS PREPARED PRIMARILY FOR INTERNAL USE WITHIN THE ATLANTIC RICHFIELD HANFORD COMPANY ANY EXPRESSED VIEWS AND OPINIONS ARE THOSE OF THE AUTHOR AND NOT NECESSARILY OF THE COMPANY.

\section{NOTICE}

THIS REPORT WAS PREPARED AS AN ACCOUNT OF WORK SPONSORED BY THE UNITED STATES GOVERNMENT. NEITHER THE UNITED STATES NOR THE UNITED STATES ATOMIC ENERGY COMMISSION, IOR ANY OF THEIREMPLOYEES, NOR ANY OF THEIR CONTRACTORS, SUBCONTRACTORS, OR THEIR EMPLOYEES, MAKES ANY WARRANTY, EXPRESS OR IMPLIED, OR ASSUMES ANY LEGAL LIABILITY OR RESPONSIBILITY FOR THE ACCURACY, COMPLETENESS OR USEFULNESS OF ANY INFORMATION, APHARATUS, PRODUCT OR PROCESS DISCLOSED, OR REPRESENTS THAT ITS USE WOULD NOT INFRINGE PRIVATELY OWNED RIGHTS. 


\section{DISCLAIMER}

This report was prepared as an account of work sponsored by an agency of the United States Government. Neither the United States Government nor any agency Thereof, nor any of their employees, makes any warranty, express or implied, or assumes any legal liability or responsibility for the accuracy, completeness, or usefulness of any information, apparatus, product, or process disclosed, or represents that its use would not infringe privately owned rights. Reference herein to any specific commercial product, process, or service by trade name, trademark, manufacturer, or otherwise does not necessarily constitute or imply its endorsement, recommendation, or favoring by the United States Government or any agency thereof. The views and opinions of authors expressed herein do not necessarily state or reflect those of the United States Government or any agency thereof. 


\section{DISCLAIMER}

Portions of this document may be illegible in electronic image products. Images are produced from the best available original document. 


\section{SPECIFICATIONS}

1.1 INTRODUCTION

1.2 FEED

1.3 ESSENTIAL MATERIALS

1.4 PRODUCT QUALITY

1.5 CHEMICAL HAZARDS

1.5.1 General

1.5.2 Radiolytic Heat

1.5.3 Hydrogen Formation

1.5.4 Organic Vapors and Solvent Nitration

1.5.5 Ammonia Hazards

1.5.6 Dissolver Erosion

1.5.7 Fluoride Corrosion

1.5.8 Waste Neutralization $\underline{\text { Page }}$

$1 \cdot 1-1$

$1.2-1$

$1 \cdot 3-1$

$1.4-1$

$1.5-1$ 


\section{STANDARDS}

\section{$\underline{\text { Page }}$}

2.1 INTRODUCTION

2.2 FEED

2.3 ESSENTIAL MATERIALS

2.4 PRODUCT QUALITY

2.5 CHEMICAL HAZARDS

2.5.1 General

2.5.2 Radiolytic Heat

2.5.3 Hydrogen Formation

2.5.4 Organic Vapors and Solvent Nitration

2.5.5 Ammonia Hazards

2.5.6 Dissolver Erosion

2.5.7 Fluoride Corrosion

2.5.8 Waste Neutralization 


\subsection{INTRODUCTION}

The process specifications and standards for thorium processing operations in the Purex Plant are presented in this document. On the basis of the thorium processing flowsheet, [1] these specifications represent currently known limits within which plant processing conditions must be maintained to meet defined product requirements safely and with minimum effect on equipment service life. The process specifications cover the general areas of (1) feed, (2) essential materials, and (3) chemical hazards. The minimum technical requirements for the uranium233. products are presented with the intent that these "best effort" or "target" values should be achieved. "Target values" are also presented for the thorium nitrate product. Criticality prevention specifications for the 1970 Thorium Campaign are presented in Reference 2.

The approvals required for these specifications and standards are designated by the individual approval sheets at the end of each section. For any revisions that may be required, it is intended that the designated level of approval also be required. A separate sheet will be provided for recording and approving such revisions for each section.

[I] ARH-1748, G.F. Smith, "Purex Plant Chemical Flowsheet for the 1970 Thorium Campaign," July 10, 1970.

[2] ARH-1514, June I, 1970, W.E. Matheison, G.C. Oberg, and G.I. Ritter, "Criticality Prevention Specifications, Thorium-Uranium-233 Separations in the Purex Plant." 


\subsection{FEED SPECIFICATIONS}

\subsubsection{Charging}

On the basis of reactor shipping records and visual observation of loaded buckets, no reactor product materials other than DUN reactor, aluminum-clad, irradiated thoria targets shall be accepted for processing at the Purex Plant during a scheduled thoria processing campaign.

\subsubsection{Scheduling}

Scheduling of the charging of the irradiated thoria target elements to the dissolvers, as based on reactor shipping records, shali satisfy the following requirements:

a. The concentration of I-13l per dissolver charge shall not average greater than 20 curies per ton of thorium.*

b. The concentration of $\mathrm{Pa}-233$ per dissolver charge shall not be greater than 1 gram per ton of thorium.

c. The calculated maximum average U-238 fraction of total uranium in a dissolver charge shall be no more than:

(1) 0.8 percent for the purge portion of the run.

(2) 0.2 percent for the product portion of the run.

d. The calculated maximum average U-232-to-U-233 mass ratio in a dissolver charge shall be no more than:

(1) $1 \times 10^{-5}$ for the purge portion of the run.

(2) $8 \times 10^{-6}$ for the product portion of the run.

* The intent of this specification is to insure that the emission of I-13I from the Purex Plant can be practicably controlled at less than 0.2 curies per day. 


\subsubsection{APPROVALS FOR SECTION 1.2}

Prepared by: $\frac{\text { Process Engineer - Separations }}{\text { Process Engineering }}-\frac{714170}{\text { Date }}$ Issued by: $\frac{\text { Y.L. fette }}{\substack{\text { Manger - Separations Process } \\ \text { Engineering }}} \frac{7-29-70}{\text { Date }}$ Approved by: $\frac{0}{\substack{\text { Manafer - Operations Support } \\ \text { Engineering }}}+7-30-70$ Accepted by: $\frac{1}{\text { Manager-Purex }} \frac{7-31-70}{\text { Date }}$ 


\subsection{ESSENTIAL MATERIALS}

1.3.1 Only those essential materials listed below shall be used for thorium processing. The specifications for these materigis shall be as defined by the Essential Materials Manual. [1]

a. Sodium hydroxide (50\% solution)

b. Nitric acid ( $57 \%$ solution)

c. Aluminum nitrate nonahydrate

d. Ferrous sulfamate

e. Phosphoric acid

f. Sugar (sucrose)

B. Normal paraffin hydrocarbon

h. Tributyl phosphate

i. Sodium nitrate

j. Sodium carbonate

k. Potassium permanganate

1. Potassium fluoride

m. Oxalic acid

n. Sodium nitrite

o. Sulfuric acid

p. Amberlite IRA-93 anion exchange resin

q. Dowex HCR-W cation exchange resin

r. Cadmium nitrate (50\% solution)

s. Dowex 50W-X8[2]

t. Dow Corning Antifoam B Emulsion[2]

u. Tartaric acid

[1] ARH-91, February 15, 1968, "Chemical Processing Division Essential Materials Manual"

Purchased as commercial product. 
1.3.2 APPROVALS FOR SECTION 1.3

Prepared by: $\frac{0(20)}{\begin{array}{l}\text { Process Engineer - Separations } \\ \text { Process Egnineering }\end{array}} \frac{7 / 4 / 7 d}{\text { Date }}$

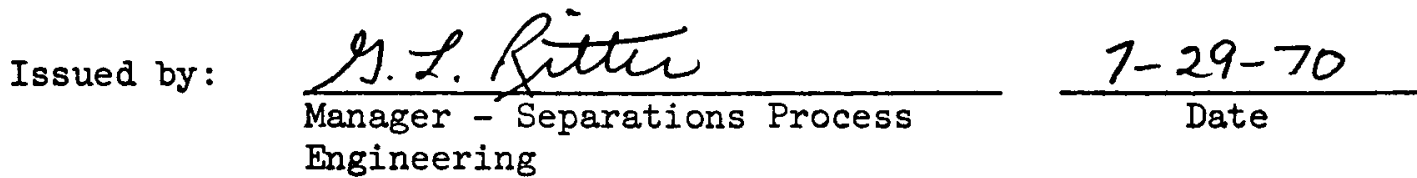
Approved by: $\frac{\text { Beamel }}{\text { Mander - Operations Support }} \frac{2-30-7)}{\text { Date }}$ Accepted by: 
1.4 PRODUCT QUALITY

The requirements for U-233 and thorium products are given in Section 2.4 . 


\subsection{CHEMICAL HAZARDS CONTROL SPECIFICATIONS}

The chemicals that are used for thorium processing and the chemical characteristics of the thorium processing streams introduce potential hazards of fire or other uncontrolled chemical reactions in the Purex Plant. The limits or restrictions necessary to maintain the probability of a hazardous incident at acceptably low levels are defined by the specifications below. They were developed in conjunction with the other specifications included in this document, and in conjunction with the chemical processes defined and recommended [1] for processing the specified feed material (Section 2.0).

\subsubsection{General}

1.5.1.1 Changes to the approved thorium processing systems that could affect the chemical hazards considerations shall be approved by the Manager, Separations Process Engineering, prior to their processing use.

1.5.1.2 Deviations from specifications shall be promptly called to the attention of the Manager, Separations Process Engineering. Plans for corrective action shall be developed promptly and shall be acted upon accordingly. The plans and procedures required for the corrective action shall be subject to approval for chemical safety considerations by the Manager, Separations Process Engineering.

1.5.1.3 The Manager, Separations Process Engineering shall revise or supplement these specifications as required to permit justified changes in the process or equipment. Supplements or revisions of these specifications require the same level of review, approval, and acceptance as the specifications themselves.

\subsubsection{Radiolytic Heat Specifications}

1.5.2.1 The quantity of radioactivity introduced to any process vessel shall be limited such that adequate cooling capacity is available for maintaining the vessel solution temperature at less than $50^{\circ} \mathrm{C}$.

\subsubsection{Hydrogen Formation Specifications}

\subsubsection{Radiolytic Formation of Hydrogen}

Vessel atmospheres shall be controlled by air dilution such that the calculated concentration of hydrogen gas

[1] ARH-1748, July 10, 1970, G.F. Smith, "Purex Plant Chemical Flowsheet for the 1970 Thorium Campaign" 
formed by solution radiolysis does not exceed two volume percent based on a hydrogen formation rate of 0.043 cubic feet per kilowatt-hour of radioisotopic energy.

\subsubsection{Chemical Formation of Hydrogen}

Sodium hydroxide shall not be added to a dissolver charge of aluminum-clad thorium slugs unless the slugs are covered with enough sodium nitrate solution of at least $0.2 \mathrm{M}$ concentration to give a mole ratio of sodium nitrate to aluminum (slug jacket) of at least 1.0 .

\subsubsection{Organic Vapors and Solvent Nitration Specifications}

\subsubsection{Definitions}

a. For purposes of these specifications, organic shall be considered to be normal paraffin hydrocarbon (NPH) diluent in any combination with tributyl phosphate (TBP).

b. For purposes of these specifications, any process stream that "might contain an organic phase" shall include any stream that has been previously in contact with an organic phase. Likewise, any vessel to which "an organic phase might be introduced" shall include any vessel that receives a stream that might contain an organic phase.

\subsubsection{Specifications}

a. Vessel Temperature

Any process vessel, including any condenser, to which an organic phase might be introduced, shall not be operated above $65^{\circ} \mathrm{C}$, except as permitted by the conditions described by (1) and (2), below.

(1) For vessels that are required to operate above $65^{\circ} \mathrm{C}$, any influent liquid process stream that might contain an organic phase shall be pretreated for organic removal by decanting or by steam stripping. If steam stripping is used, the weight ratio of steam vapor to liquid shall be at least 0.5 .

(2) Vessels containing solutions that have contacted an organic phase and have not been steam 
stripped or decanted shall be operated above $65^{\circ} \mathrm{C}$ only under the conditions outlined in a special procedure approved by the Manager, Separations Process Engineering. The maximum solution temperature in any vessel containing solution which has contacted a solvent phase and has undergone subsequent steam stripping or decanting shall be $125^{\circ} \mathrm{C}$, as measured by in-vessel thermohms.

\section{b. Heat Transfer Surface Temperature}

Tube Bundle Surface Temperature: The concentrators shall be operated at or below the following maximum tube bundle steam pressures (and corresponding tube bundle surface temperatures) as measured by steam line pressure gauges:

$$
\begin{array}{ll}
\text { E-K4, E-J8, E-H4, E-N6 } & 29 \text { psig (135 } \mathrm{C}) \\
\text { E-F6 } & 39 \mathrm{psig}\left(141^{\circ} \mathrm{C}\right)
\end{array}
$$

\subsubsection{Ammonia Hazards Control Specifications}

To prevent the formation of flammable ammonia-air mixtures in the Purex Plant during the run, the following specifications are required.

\subsubsection{Dissolver System}

a. During the coating removal operation, the unheated dissolver off-gas shall be maintained at less than 14 volume percent of ammonia by controlling the. sodium hydroxide addition rate.

b. During the coating removal operation, the ammonia scrubber water rate shall be a minimum of 7 gallons per minute.

c. The silver reactor influent gas shall be maintained between 350 and $400^{\circ} \mathrm{F}$ during coating removal and dissolution.

\subsubsection{Waste Neutralization}

During waste neutralization in $\mathrm{TK}-\mathrm{F} 15, \mathrm{TK}-\mathrm{F} 16$, and TK-FI8, the atmosphere in the tank shall contain sufficient water vapor to prevent a flammable mixture of air and ammonia by controlling the tank temperature.

\subsubsection{Dissolver Erosion Specifications}

In order to prevent erosion of the dissolver bottoms beneath the lifter-circulators, the impinging air velocity shall be no 
greater than 55 feet per second by controlling the air to the spargers.

\subsubsection{Fluoride Corrosion Control Specifications}

Fluoride-induced corrosion of stainless steel equipment shall be minimized by maintaining a mole ratio of complexing (aluminum or thorium) ions to fluoride ions in excess of 3 to 1 in those process solutions where the fluoride ion concentration exceeds $0.001 \mathrm{M}$.

\subsubsection{Sugar Denitration Specifications}

To prevent uncontrolled reactions between sugar and nitric acid in the waste treatment system the following specifications are required.

\subsubsection{Sugar Routing}

Solutions containing sugar shall not be added from AMU vessels to canyon vessels other than TK-F7, TK-FI5 and TK-FI6.

\subsubsection{Temperature}

Whenever sugar solution* is added to E-F6, TK-FI5 or TK-F16, the temperature shall exceed $90^{\circ} \mathrm{C}$.

\subsubsection{Sugar Concentration}

a. The maximum concentration of sugar in the IWF Tank (TK-F7) shall be $0.005 \mathrm{M}$. This can be accomplished by maintaining the flow ratio of IWF to IWF-Sugar greater than 140 .

b. The maximum amount of sugar added to TK-F15 or TK-F16 shall be less than 0.073 moles of sugar per mole of nitric acid ( 0.40 pounds of sugar per pound of nitric acid).

\subsubsection{Tank Pressurization}

Addition of solution conteining sugar to any canyon vessel that is pressurized with respect to the canyon cell in which the vessel is located shall be terminated and/or prohibited.

* Solution transfers resulting from normal processing of waste in E-F6 through $\mathrm{TK}-\mathrm{F} 26$ to $\mathrm{TK}-\mathrm{F} 15$ and $\mathrm{TK}-\mathrm{F} 16$ are exempt from this requirement. 


\subsubsection{Waste Neutralization Specifications}

All wastes routed to underground storage tanks shall be neutralized as follows:

a. Sugar denitrated solvent extraction wastes shall have a $\mathrm{pH}$ of 11 or greater.

b. All other equipment flushes and thorium processing wastes shall have a pH of 8 or greater. 
UNCLASSIFIED

1.5.10 APPROVALS FOR SECTION 1.5
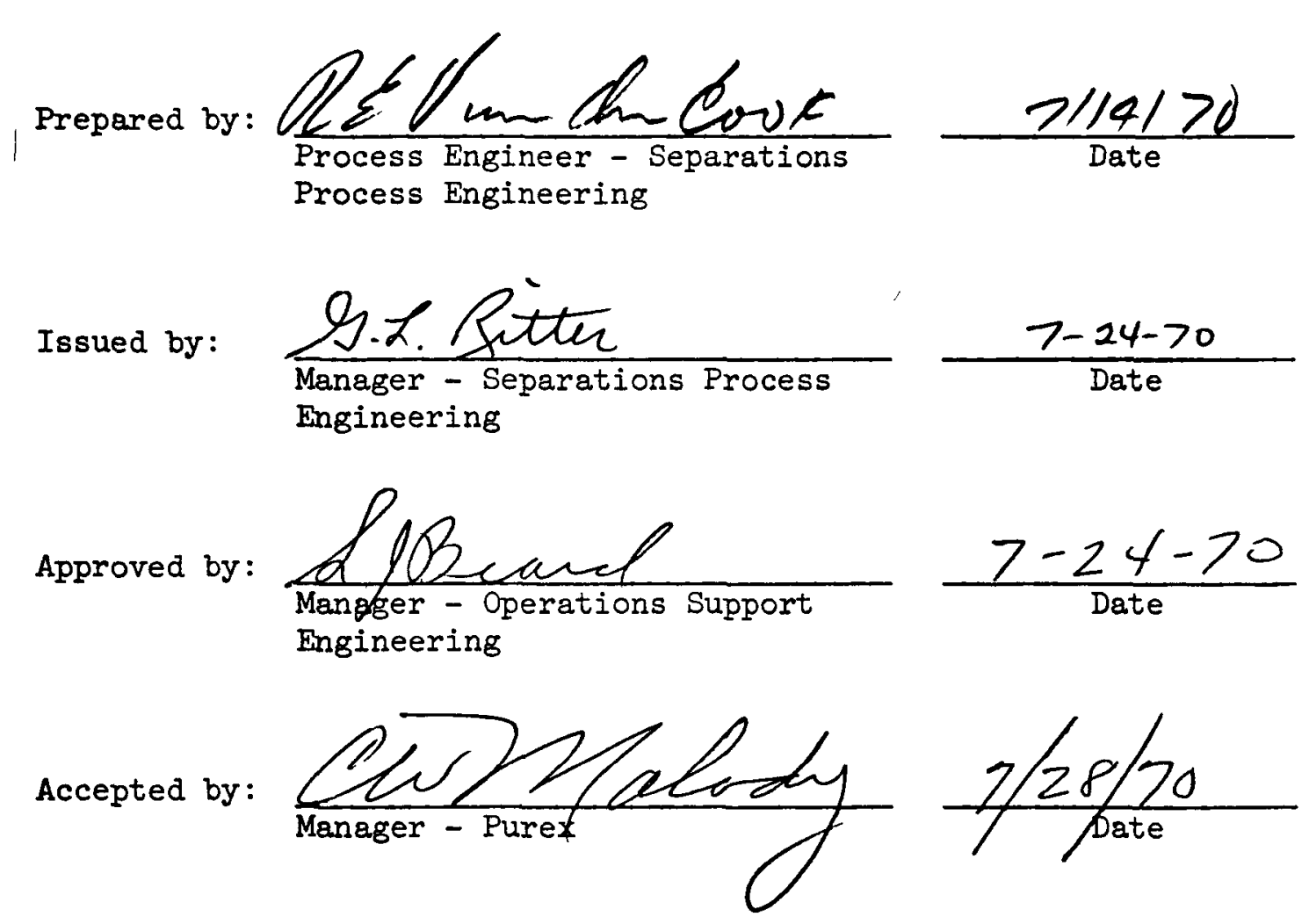

ARH-1757

Page $1.5-6$

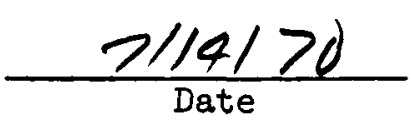

$$
\frac{7-24-70}{\text { Date }}
$$

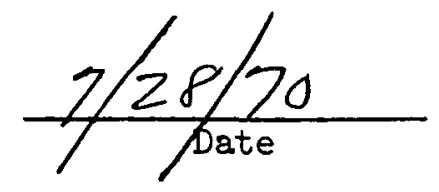

UNCLASSIFIED 


\subsection{INTRODUCTION}

The standards defined in the following sections were selected to define the actions required to implement the specifications in the preceeding sections. Any revisions require the same level of approval as the original standards. 


\subsection{FEED STANDARDS}

\subsubsection{Charging}

Prior to charging each bucket, a visual inspection of the bucket contents shall be made to guard against inadvertent charging of fuel other than thoria targets.

\subsubsection{Scheduling}

The reactor shipping records may be compared with dissolver charge shcedules to satisfy the specifications. Other arrangements may also satisfy the specification requirements. 


\subsubsection{APPROVALS FOR SECTION 2.2}

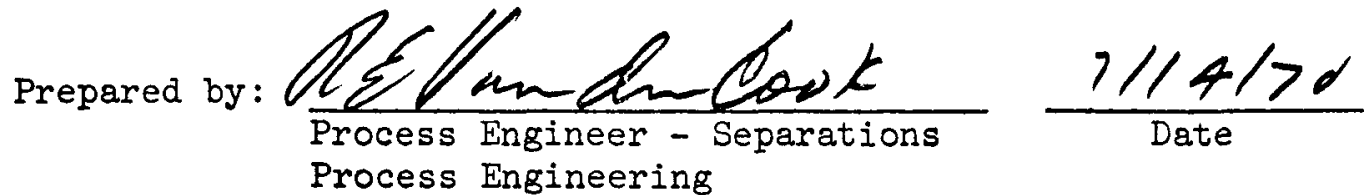

Issued by: $\frac{\text { S.2. fitte }}{\substack{\text { Manager - Separations Process } \\ \text { Engineering }}} \frac{8-3-70}{\text { Date }}$

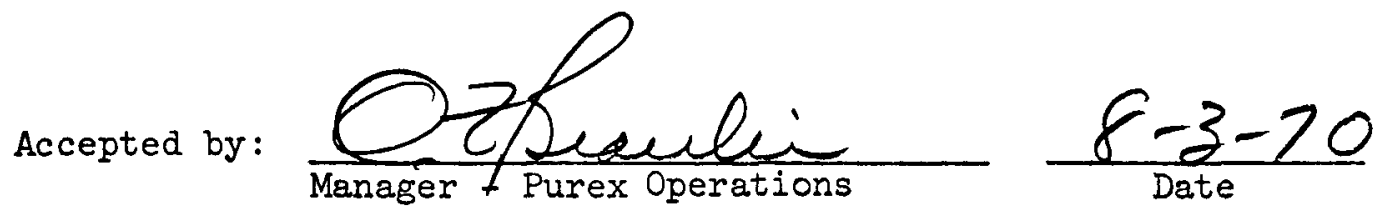


2.3 ESSENTIAL MATERIAL STANDARDS

Specifications for essential materials are presented in Section 1.3 . 


\subsection{PRODUCT QUALITY}

\subsubsection{Basis}

The capability of the thorium processing flowsheet for consistently producing uranium-233 and thorium nitrate products of a specified quality has not been demonstrated. Hence, firm product specifications have not been defined. Instead, minimum technical requirements for the U-233 and purity goals for the thorium are proposed on the basis of (a) requirements of product customers, (b) process performance estimates by Separations Process Engineering, and (c) potential reuse of the thorium nitrate product. These requirements should also provide product of adequate purity for any on-site processing that might be subsequently planned.

\subsubsection{General}

a. Additions and revisions to these goals shall be made by mutual agreement of the Manager, Purex Operations, and the Manager, Separations Process Engineering.

b. Failure to meet any of these goals shall be investigated and the cause corrected, as possible, to the mutual satisfaction of the Manager, Purex, and the Manager, Separations Process Engineering.

\subsubsection{Minimum Technical Requirements for Uranium-233}

\subsubsection{Basis}

The sampling, analytical requirements and purity requirements presented in this section are required to provide a product suitable for use by the customer.

\subsubsection{Sampling}

A $100 \mathrm{ml}$ plastic bottle sample shall be obtained of each $12 \mathrm{~kg}$ maximum product batch in $\mathrm{TK}-\mathrm{L} 9$. The customer requires four samples, containing 4 to $6 \mathrm{gm}$ of U-233, representative of the third, tenth, twentieth, and the thirtieth $12 \mathrm{~kg}$ increment of contained U-233 shipped to the user. These shall be forwarded to the customer within one month after manufacture. 


\subsubsection{Analytical Methods}

The analytical methods presented below reflect the most satisfactory methods currently available. Any improved methods subsequently developed may be used with the concurrence of the Manager, Separations Chemistry Laboratory, but the Manager, Separations Process Engineering should be so advised.

2.4.3.4 Product Quality

\section{Component}

a. Nitric Acid

b. Uranium Concentration

c. Uranium isotopic concentration* (based on total U)
Suggested

Technical Analytical Requirement Method

Report $\quad \mathrm{HVC}-21 \mathrm{C}$
measured value $300-375 \mathrm{~g} / \mathrm{I} \quad \mathrm{UC}-2 \mathrm{Cl}$

\section{Average for the Run}

$\begin{array}{lrl}U-232 & 8 & \text { ppm } \max . \\ \mathrm{U}-233 & 97 \mathrm{wEA} \\ \mathrm{U}-234 & 2.5 \mathrm{w} / 0 \mathrm{~min} . \\ \mathrm{U}-235 & 0.5 \mathrm{w} / 0 \mathrm{max} . \\ \mathrm{U}-236 & 0.1 \mathrm{w} / 0 \mathrm{max} . \\ -\mathrm{U}-238 & 0.5 \mathrm{w} / 0 \mathrm{max} .\end{array}$

d. Impurities - The average impurity content of the total order quantity of purified material shall not exceed a total Neutron Poison Equivalence of 260.** In addition, no impurity shall exceed the indicated maximum individual impurity limits specified below, for any analysis:

* For uranium-235 and -236 isotopic analysis, the precision of reported values shall be equal to or smaller than \pm 0.01 weight percent (absolute). For uranium-234 and -238 , this precision shall be equal to or smaller than \pm 0.02 weight percent (absolute).

* The total Neutron Poison Equivalence is determined by calculating the sum of the product of (ppm of impurity) times (neutron poison equivalence factor of the impurity). Limits of detection shall be used in calculatirg the neutron poison equivalence when results of analysis are below these limits. 


\begin{tabular}{|c|c|c|c|}
\hline Impurity & $\begin{array}{c}\text { Neutron Poison } \\
\text { Equivalence } \\
\text { Factor } \\
\end{array}$ & $\begin{array}{c}\text { Maximum } \\
\text { Individual } \\
\text { Impurity } \\
\text { Limit (ppmoun) } \\
\end{array}$ & Method* \\
\hline $\begin{array}{l}\text { Aluminum (Al) } \\
\text { Boron (B) } \\
\text { Calcium (Ca) } \\
\text { Cadmium (Cd) } \\
\text { Chlorine+Bromine ( } \mathrm{Cl}+\mathrm{Br})\end{array}$ & $\begin{array}{l}0.01 \\
30.0 \\
0.07 \\
2.3 \\
1.2\end{array}$ & $\begin{array}{r}300 \\
3 \\
100 \\
5 \\
40\end{array}$ & $C 1 N-2 a$ \\
\hline $\begin{array}{l}\text { Cobalt (Co) } \\
\text { Chromium ( } \mathrm{Cr}) \\
\text { Copper (Cu) } \\
\text { Mercury ( } \mathrm{Hg}) \\
\text { Iron (Fe) } \\
\text { Potassium (K) }\end{array}$ & $\begin{array}{l}1.0 \\
0.07 \\
0.09 \\
- \\
0.06 \\
0.06\end{array}$ & $\begin{array}{r}25 \\
100 \\
150 \\
50 \\
1,000 \\
200\end{array}$ & $\mathrm{HgS}-\mathrm{a}$ \\
\hline $\begin{array}{l}\text { Magnesium ( } \mathrm{Mg}) \\
\text { Manganese (Mn) } \\
\text { Molybdenum (Mo) } \\
\text { Sodium (Na) } \\
\text { Nickel (Ni) }\end{array}$ & $\begin{array}{l}0.03 \\
0.34 \\
0.11 \\
0.02 \\
0.11\end{array}$ & $\begin{array}{r}150 \\
50 \\
100 \\
300 \\
200\end{array}$ & \\
\hline $\begin{array}{l}\text { Neptunium (Np) } \\
\text { Phosphorus (P) } \\
\text { Plutonium (Pu) (Total) } \\
\text { (Pu)238 } \\
\text { Silicon (Si) }\end{array}$ & $\begin{array}{l}2.4 \\
0.03 \\
- \\
1.05 \\
0.02\end{array}$ & $\begin{array}{r}100 \\
150 \\
150 \\
25 \\
300\end{array}$ & $\begin{array}{l}\text { NpA-6c } \\
\text { PuA-30a } \\
\text { Ratio }\end{array}$ \\
\hline $\begin{array}{l}\text { Thorium (Th) } \\
\text { Titanium (Ti) } \\
\text { Vanadium (V) } \\
\text { Tungsten (W) } \\
\text { Zinc }(\mathrm{Zn})\end{array}$ & $\begin{array}{l}- \\
0.16 \\
0.13 \\
0.50 \\
0.02\end{array}$ & $\begin{array}{r}1,000 \\
75 \\
100 \\
20 \\
100\end{array}$ & THS-1x \\
\hline
\end{tabular}

*By emission spectrograph except as noted.

e. Radioactivity

(1) Alpha Activity - Gross alpha activity at the time of separation shall be no more than $2.6 \times 10^{10} \mathrm{~d} / \mathrm{m} /$ gram of product.

(2) Gamma Activity - Activity of gamma-emitting isotopes, time corrected to the completion of purification of U-233, shall be less than: 
UNCLASSIFIED

Component

Th 228

Sum of $\mathrm{Pa}-233, \mathrm{Zr}-\mathrm{Nb}-$ 95, Ru total and Th-228 daughters*
ARH-1757

Page 2.4-4

Target Iimit

$0.84 \mu \mathrm{Ci} / \mathrm{gram}$ of Uranium

$22 \mu \mathrm{Ci} / \mathrm{gram}$ of

Uranium

\subsubsection{Thorium Product}

2.4.4.1 Basis

The sampling and analytical requirements and purity goals presented in this section should provide a thorium (TNT) nitrate tetrahydrate product of adequate purity for recycling to the reactors.

\subsubsection{Sampling}

A bottle sample (150-200 ml) should be obtained from each batch of TNT product in $\mathrm{TK}-\mathrm{K} 6$. An aliquot sufficient for the Purex analytical requirements is removed and the remainder held for compositing.

\subsubsection{Analytical Methods}

The suggested analytical methods presented below reflect the most satisfactory methods currently available. Any improved methods subsequently developed may be used, with the concurrence of the Manager, Separations Chemistry Laboratory; but the Manager, Separations Process Engineering should be so advised.

2.4.4.4 Product Quality

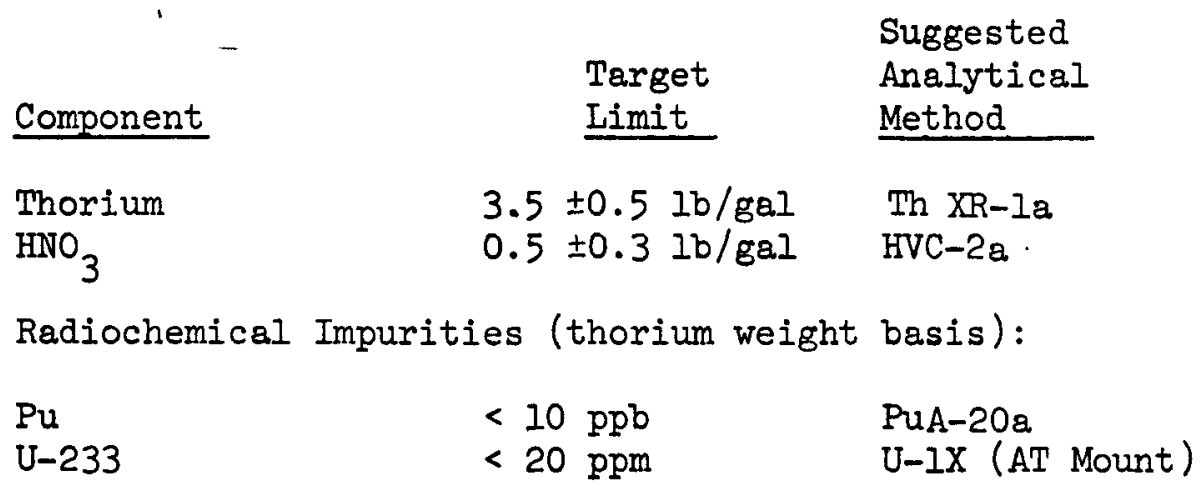

$\mathrm{Ra}-224, \mathrm{Rn}-220, \mathrm{~Pb}-212, \mathrm{Bi}-212, \mathrm{Tl}-208$ 
Component

Total U (Excluding

U-233)
ZrNb-95
Ru-103, RuRh-106
Pa-233

< $10 \mathrm{ppm}$

$<50 \mu \mathrm{Ci} / \mathrm{Ib}$

$<50 \mu \mathrm{Ci} / 1 \mathrm{~b}$

$<300 \mu \mathrm{Ci} / \mathrm{Ib}$
Suggested

Target Analytical

Limit

Method

Chemical Impurities (Thorium weight basis):

\begin{tabular}{|c|c|c|c|}
\hline $\begin{array}{l}\text { Silicon } \\
\text { Iron } \\
\text { Total Impurities * } \\
\text { Chloride } \\
\text { Sulfate }\end{array}$ & $\begin{array}{l}<50 \\
<100 \\
<1000 \\
<50 \\
<200\end{array}$ & $\begin{array}{l}\text { ppm } \\
\text { ppm } \\
\text { ppm } \\
\text { ppm } \\
\text { ppm }\end{array}$ & $\begin{array}{l}\text { Emission Spec. } \\
\text { Emission Spec. } \\
\text { Emission Spec. } \\
\text { To be determd. } \\
\text { To be determd. }\end{array}$ \\
\hline
\end{tabular}

* $\mathrm{Al}, \mathrm{B}, \mathrm{Be}, \mathrm{Bi}, \mathrm{Ca}, \mathrm{Cd}, \mathrm{Co}, \mathrm{Cr}, \mathrm{Cu}, \mathrm{Fe}, \mathrm{K}, \mathrm{Ii}, \mathrm{Mg}$, $\mathrm{Mn}, \mathrm{Na}, \mathrm{Ni}, \mathrm{P}, \mathrm{Pb}, \mathrm{Si}, \mathrm{Sn}, \mathrm{Zn}$ 
UNCLASSIFIED

2.4.5 APPROVALS FOR SECTION 2.4
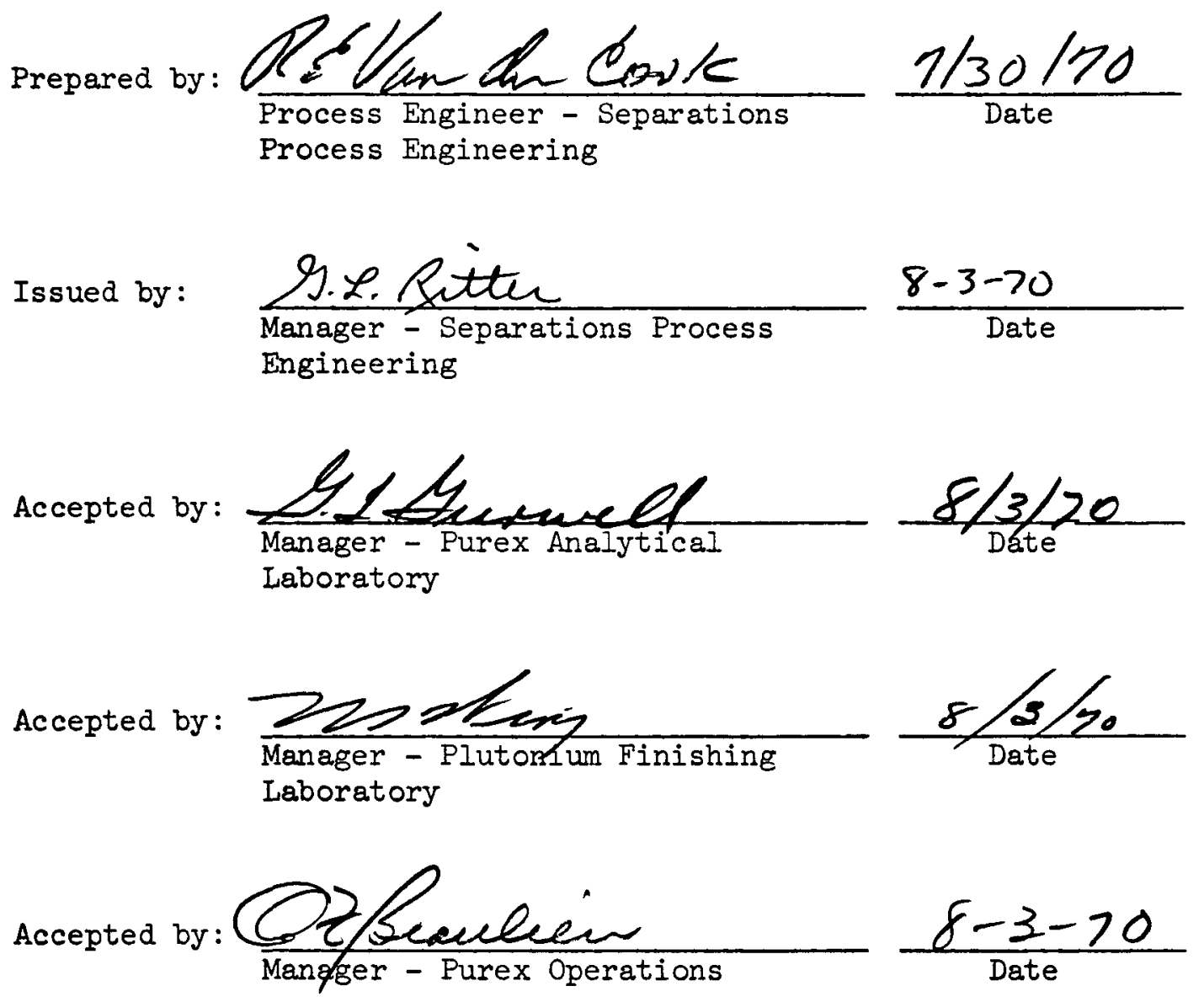

UNCLASSIFIED 


\section{REVISION APPROVALS FOR SECTION 2.4}

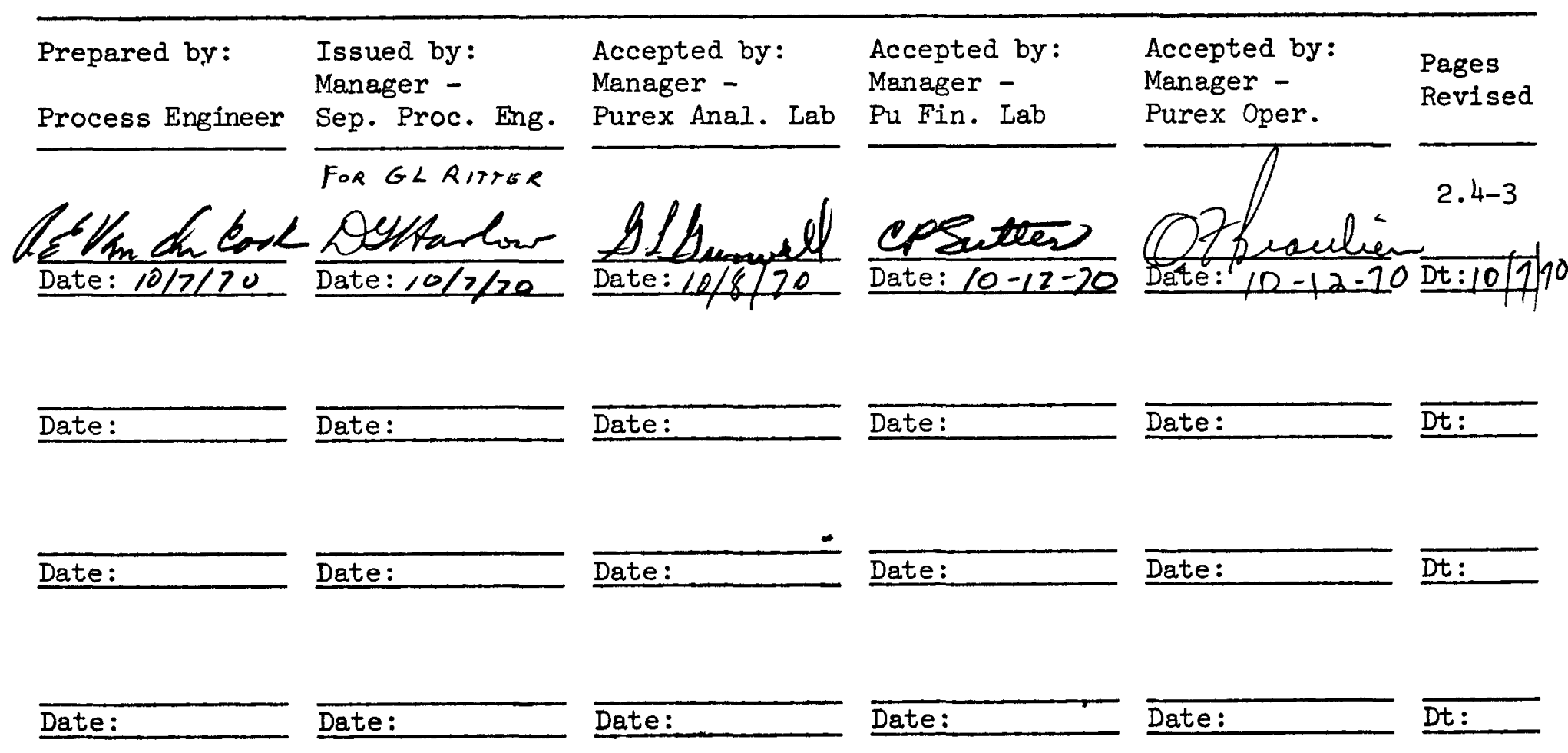




\subsection{CHEMICAL HAZARDS CONTROL STANDARDS}

The limits defined by these standards are such that the corresponding Chemical Hazards Control Specifications will not be exceeded.

\subsubsection{General}

Additions or revisions to the standard require the same level of approval as the standards themselves.

\subsubsection{Radiolytic Heat Standards}

Heat generation in the thorium solutions for the 1970 campaign is minimal due to the long aging time. Total heat contained is less than 70,000 BTU per hour as of July 1, 1970. The cooling capabilities of all process tanks is shown in the table below.

\section{Vessel}

a. Standard Purex Vessel (TK-D1, D2, D5, E3, E5, E6, $\mathrm{F} 3, \mathrm{~F} 4, \mathrm{~F} 7, \mathrm{~F} 5, \mathrm{~F} 10, \mathrm{~F} 12$, F13, F15, F16, F18, G8, H1, $\mathrm{Jl}, \mathrm{J} 3, \mathrm{Kl}, \mathrm{K} 5, \mathrm{~K} 6$ )

b. Tanks El, G2

c. Purex Annular Dissolver
Cooling Capabilities*

$>500,000 \mathrm{BTU} / \mathrm{hr}$

\subsubsection{Hydrogen Formation Standards}

a. Radiolytic Formation of Hydrogen

Based on the average expected heat content in the thoria, the maximum hydrogen evolution rate in a Purex tank is expected to be 0.01 cubic feet per hour. Addition of 1 cubic foot per hour of air shall be maintained to dilute this to a safe concentration.

b. Chemical Formation of Hydrogen

(1) For a standard charge the dissolver should contain at least 1,370 pounds of sodium nitrate (dry basis).

(2) During the addition of sodium hydroxide to a dissolver, the solution in the dissolver shall be agitated by boiling or air sparging.

* Assumes $40^{\circ}$ solution temperature and a cooling water temperature of $20^{\circ} \mathrm{C}$ and a heat transfer coefficient of $50 \mathrm{BTU} / \mathrm{hr}-\mathrm{ft}^{2} \mathrm{o}^{\circ} \mathrm{F}$. 


\subsubsection{Organic Vapor and Solvent Nitration Standards}

2.5.4.1 The following streams shall be decanted in the corresponding tank:

$\begin{array}{lll}\text { Stream } & \text { Tank } & \text { Concentrator } \\ \text { IWF } & \text { F7 } & \text { E-F6 } \\ \text { 3BU } & \text { NI } & \text { E-N6 }\end{array}$

2.5.4.2 The following streams shall be routed to the tower of the appropriate concentrator for steam stripping:

\begin{tabular}{lc} 
Stream & Concentrator \\
\cline { 2 - 2 } IBT & E-J8 \\
ICU & E-H4 \\
2ET & E-K4
\end{tabular}

\subsubsection{Steam Stripping}

Effective control of the steam stripping operation shall be maintained by (1) initially starting up the concentrators by establishing and maintaining the boiling of solvent-free solutions (such as water, fresh acid, or concentrator bottoms from previous operation), and (2) introduction of the process solutions to a steam stripping tower (T-J8, T-K4, T-H4).

\subsubsection{Decanting}

The feed solutions to concentrators E-F6 and E-NG shall be pumped from unagitated tanks (TK-F7, TK-NI) in whicil the pump suctions are covered with aqueous solutions.

\subsubsection{Vessel Pressure}

The concentrator systems (E-J8, E-K4, E-H4, E-F6, E-N6) shall not be operated under positive pressure as measured by pot vacuum and differential pressure instrumentation. Accidental pressurization (positive) shall be immediately corrected.

\subsubsection{Temperature Control}

The concentrators and appropriate tanks (with the exception of the E-FIl Concentrator) are equipped with high 
temperature alarms set at $120^{\circ} \mathrm{C}$. If any vessel solution temperature exceeds $120^{\circ} \mathrm{C}$ (except E-FII concentrator), immediate action shall be taken to keep the temperature below the $125^{\circ} \mathrm{C}$ maximum.

\subsubsection{Tank Heating}

Tanks which contain organic phase and/or aqueous which may contain organic phase shall not be heated unless the liquid level completely covers the coil or the temperature of the liquid medium supplied to the coil is less than $65^{\circ} \mathrm{C}$.

\subsubsection{Dissolvers and Acid Boil-Off Vessel}

No stream which might contain organic shall be routed to the dissolvers $\mathrm{A} 3, \mathrm{~B} 3$ or $\mathrm{C} 3$, any $\mathrm{D}$ Cell vessels, or to E-FII.

\subsubsection{Ammonia Hazards Control Standards}

\subsubsection{Dissolver System}

The maximum $\mathrm{NaOH}$ addition rate to a dissolver containing aluminum metal and sodium nitrate solution shall be limited to less than 33 pounds per minute of 50 percent solution. The addition of $\mathrm{NaOH}$ to a dissolver shall be terminated and/or prohibited whenever the vessel is pressurized with respect to the cell.

2.5.5.2 The minimum solution temperature during waste neutralization in vessels $\mathrm{TK}-\mathrm{F} 15, \mathrm{TK}-\mathrm{F} 16$ and $\mathrm{TK}-\mathrm{F} 18$, shall be $45^{\circ} \mathrm{C}$ as measured by in-vessel thermohms.

Note: See Section 2.5 .4 for maximum operating temperatures.

\subsubsection{Dissolver Erosion Standards}

2.5.6.1 The maximum air supplied to the inner annulus liftercirculator shall not exceed 300 scfm or 21 psi pressure drop on sparger orifices.

2.5.6.2 The air supplied to the outer annulus lifter-circulator shall not exceed 260 scfm or 21 psi pressure drop.

\subsubsection{Fluoride Corrosion Control Standards}

Aluminum nitrate shall be added to the dissolvers TK-A3, B3, C3, $\mathrm{TK}-\mathrm{F} 5$ and $\mathrm{TK}-\mathrm{F} 3$ as required to maintain an $\mathrm{Al}$, (or $\mathrm{Th}$ ) to $\mathrm{F}$ mole ratio of at least 3.0 . 


\subsubsection{Sugar Denitration Standards}

\subsubsection{Sugar Concentration}

a. The sugar concentration in TK-204 shall be less than 23.5 weight percent.

b. The maximum amount of sugar solution added to TK-F15 shall be less than 1.4 pounds of solution per pound of nitric acid in TK-F15.

2.5.9 Waste Neutralization Standards

2.5.9.1 Waste Routing

Wastes from thorium processing shall be routed to non-boiling storage via the 104-C pump tank.

\subsubsection{Flushes}

The sum of the $\mathrm{Zr}-\mathrm{Nb}-95, \mathrm{Ru}-103, \mathrm{RuRh}-106$ and $\mathrm{CePr}-144$ in neutralized flushes routed to non-boiling storage during the thorium campaign shall not exceed a concentration of $3.5 \times 10^{7} \mathrm{\mu Ci} /$ gal or a total of $2.0 \times 10^{6}$ curies.

\subsubsection{Records}

Inventory records of batch volumes and Cs-137 concentration* for all waste transfers to non-boiling storage shall be maintained by Purex Operation Subsection and reported weekly to the Manager, Separations Process Engineering, for transmittal to the Manager, Waste Management Process Engineering.

* Cs-137 content may be determined from weekly composite samples. 


\subsubsection{APPROVALS FOR SECTION 2.5}

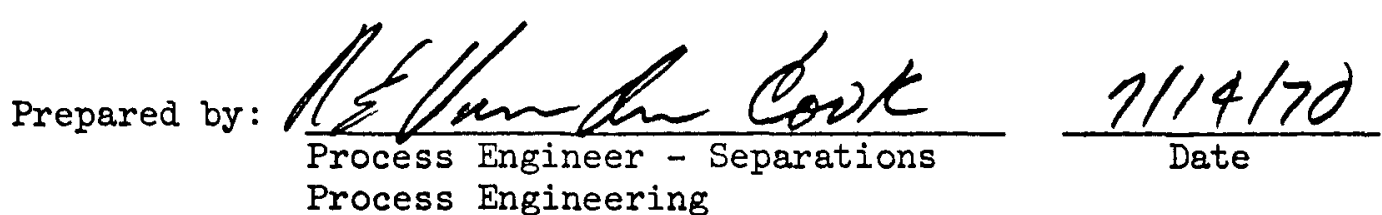

Issued by: $\frac{92 / \text { fith }}{\text { Manager - Separations Process }} \frac{7-24-70}{\text { Date }}$ Engineering

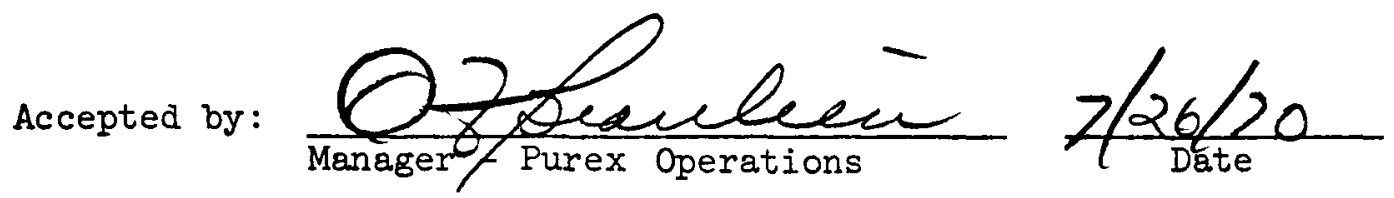

